\title{
Ödev Etiğinin Dini Etik Açısından Değerlendirilmesi
}

\section{Dr. Öğr. Üyesi Ali Yıldırım ${ }^{1 *}$}

Geliş tarihi: 09.09.2019

Kabul tarihi: 01.10.2019

\section{Atıf bilgisi:}

IBAD Sosyal Bilimler Dergisi

Sayı: Özel Sayı Sayfa: 508-519

Yıl: 2019

This article was checked by iThenticate. Similarity Index $15 \%$.

1 Tokat Gaziosmanpaşa Üniversitesi, Türkiye, oklubali@hotmail.com ORCID ID 0000-0003-1687-993X

* Sorumlu yazar

\section{ÖZ}

Kant, ödev etiğini insanın özgürlüğü, ruhun ölmezliği ve Tanrı'nın varlığ postulatları üzerine inşa etmiştir. Bu postulatlar aynı zamanda, onun etik anlayışının Dini etik ile benzer ve farklı yönlerine dair fikirler vermektedir. Dini etik, insandan Tanrı tarafindan gönderilen ahlak yasasına tam bir teslimiyeti ister. Ödev etiğinde ise ahlak yasasına uyma temayülü dışsal bir motivi aşar. İnsanın, bilerek, isteyerek ve her tür dışsal etkiden, arzu ve beklentilerini tetikleyecek etkenlerden arınmış bir duyguyla eylemini seçmesi gerekmektedir. Diğer taraftan "ödev" kavramı, insana insan olması bakımından tabiatına uygun davranma yükümlülügünü hatırlatır. Kant, bir bakıma ödevin, Tanrı'nın hatırlatmasına gerek kalmaksızın, akıl sahibi insanın, yapması gerekeni bizzat kendi aklı ile bilinçli olarak ve arzu ederek yapması gerektiğinden bahseder. Ancak pratikte işler Kant'ın istediği gibi gitmeyebilir ve bu nedenle de Kant'in ödev etiği idealist bir teori olarak değerlendirilir. Bu noktada dini etiğinin fonksiyonu devreye girer ve Kant'ın idealinde de yer alan "herkesin isteyebileceği faydayı gözeten kurallardan" bahseder. Kant'ın, ahlaki değerlerin kaynağını Tanrı olarak gösterdiği ve Tanrı'ya dayalı değerlerin nesnelliğine işaret ettiği birçok ifadesine rastlamaktayız. Kant, ahlaki dine dair düşüncelerini ifade ederken, "kalplerin, Tanrı'nın emirleri gibi tüm insani ödevleri yerine getirmeye yatkın" oluşundan söz eder. Sonunda dinin biraz farklı bir tanımına ulaşan Kant, "din tüm ödevlerin Tanrı'nın emirleri olarak kabul edilmesidir" der. Dolayısıyla konuya ilişkin görüşleri diğer eserleri ile birlikte okunduğunda, Kant'ın ahlak metafiziğinin gözden geçirilmiş bir tür dini etik olduğu fark edilmektedir. Öyle ki Kant, kalıplaşmış dini pratiklerle statik bir hal alan tanrısal buyruğun, tüm ilintilerinden styrılarak insan doğasına uygun bir formunu idealize etmektedir. Bu nedenle bu çalışma, Kant'ın ödev etiğinin nihai anlamda bir tür dini etiğe dönüşmek durumunda kaldığını iddia eder.

Anahtar Kelimeler: Kant, Gazzâlî, Ödev Etiği, Dini Etik, İlahi Buyruk 


\title{
Evaluation of Duty Ethics from the Perspective of Religious Ethics
}

\author{
Assist. Prof. Dr. Ali Yıldırım ${ }^{*}$
}

First received: 09.09 .2019

Accepted: 01.10.2019

\section{Citation:}

IBAD Journal of Social Sciences

Issue: Special Issue Pages: 508-519

Year: 2019

This article was checked by iThenticate Similarity Index $15 \%$.

1 Tokat Gaziosmanpaşa University, Turkey,oklubali@hotmail.com, ORCID ID 0000-0003-1687-993X

\footnotetext{
* Corresponding Author
}

\begin{abstract}
Kant built his work ethic on the postulates of human freedom, the immortality of the soul and the existence of God. At the same time, these postulates give ideas about the similar and different aspects of his ethics. Religious ethics demands a complete submission to the moral law sent by God from God. In the ethics of duty, the tendency to comply with the moral law exceeds an external motivation. One needs to choose the action, purposely, willingly and willingly, from all kinds of external influences, free from the factors that trigger their desire and expectations. On the other hand, the concept of "duty" reminds the person of his / her obligation to act in accordance with his / her nature as being human. Kant, in a way, mentions that the duty must be done by the person who has reason to do what he must do, consciously and with the desire, without God's reminder. In practice, however, the works may not go as Kant wants, and therefore duty ethics is considered an idealistic theory. At this point, the function of religious ethics comes into play and mentions the rules that consider the benefits that everyone in the ideal of Kant may want. We come across many statements that Kant portrays the moral values as God, and points to the objectivity of God-based values. Kant expresses his thoughts on moral religion and speaks of the tendency of hearts to fulfill all humanitarian tasks such as God's commandments. Finally, Kant, who came to a slightly different definition of religion, says that religion is accepted as the orders of God. Therefore, when his views on the subject are read in conjunction with his other works, it is recognized that Kant's moral metaphysics is a revised type of religious ethics. Thus, Kant idealizes a form that conforms to human nature by breaking away from all religions of the divine command, which becomes static with stereotyped religious practices. Therefore, this study claims that Kant's duty ethic must be transformed into religious ethics.
\end{abstract}

Keywords: Kant, Gazzâlî, Duty Ethics, Religious Ethics, Divine Command 


\section{GİRIŞ}

Ahlakın dine dayalı olarak düşünülmesi onun Tanrısal olarak anılmasını ifade eder. Buna göre, kâinatı yaratan Tanrı, onu ve içindeki her şeyi tam ve mükemmel olarak yarattıysa o halde mükemmel iyiyi de ancak O yaratmıştır. Dolayısıyla O olmasaydı en üstün iyi de olmayacaktı. Bu nedenle iyi ile ilgilenen etik, mutlak varlığ 1 için doğrudan Tanrı'ya dayandırılır. Tanrı'ya olan bağlılığın da doğal olarak dine olan bağl1lığ gerektirdiği varsayılırsa o halde etik, dine dayalı olarak anlaşılmalıdır (Berg, 1991, s. 525). Dinler, bağl1ları için birtakım ilkeler vaz eder ve bu ilkeleri onlar için kurtuluş vesilesi olarak önerirler. Tanrı'ya inananlar hayatlarının her anının O'nun emirleri ile anlam kazandığını kabul ederler. Bir dine inanmak etik açıdan neyin doğru neyin yanlış olduğu konusunda O'nun emirlerine boyun eğmeyi ve yasaklarından kaçınmayı gerektirir. Bununla birlikte dini etik farklı dinler içerisinde, muhatapları tarafından farklı biçimlerde yorumlanmış ve neticede farklı teorilerle ortaya çıkmış durumdadır. İki büyük semavi dinin etik teorilerine kısaca baktı̆̆ımızda Hıristiyanlıkta ve İslamiyet'te dini etiğe dair pek çok teori karşımıza çıkmaktadır.

Stroll, Hristiyan etiğini Pastoral Hristiyan etiği, Kilise etiği ve Reform sonrası etik olmak üzere üç aşamada değerlendirir (Stroll vd 1956, s. 29-32). Buna göre Pastoral Hristiyan etiği, Yahudi ve Pers dinlerinden etkiler barındırmakta, On Emiri, İsa'nın öğretilerini ve törenleri esas almaktadır. Bu etikte felsefi tartışmalardan ve ihtilaflardan uzak, İsa'nın öğretilerinde kendisini ifade eden bir ilahi buyruğun kılavuzluğuna teslimiyet söz konusudur. Kilise etiği, sosyal, siyasal ve dini bir kurum olarak gelişme gösteren Katolik kilisesi elinde şekillenmiştir. Ölümsüzlük üzerine tartışmalar, rahip ve rahibe manastırlarının ortaya çıkmasıyla birlikte ruhbanlık kavramına getirilen yorumlar, sosyal hayata müdahale konusunda kilise-devlet mücadelesinin doğurduğu etik tartışmalar ve Luther'in kiliseden ayrılmasına neden olan yorumsal güçlükler, Kilise etiğinin genel karakterini sürekli etkilemiş ve değişikliklere uğratmıştır. Reform sonrası Protestanlığın gelişmesiyle ortaya çıkan etik öğreti ise daha çok Katolik etik öğretinin görüşlerini reddeden bir duruş benimsemiştir. Tüm bu çeşitliliğe ve çelişkilere karşın Hıristiyan etiğinin temeli, dolayısıyla bir Hristiyan'ın nasıl yaşaması gerektiği tanrısal buyruğun bir ifadesi olarak İsa'nın vaazlarında yer alır. Hristiyan etiği, genel karakteri itibariyle ahlak kurallarını belirleyen ilahi bir varlığa inanmayı gerektir. Ahlaklı olmak için bu ilahi varlığın doğru dediğine uygun eylemde bulunmak ve yasaklarından sakınmak gerekir. Hristiyan vahyinde ve özellikle Yeni Ahitte ortaya konan dini ahlak daha sonra Aziz Augustinus (350-430), Petrus Abelardus (1079-1142) Thomas Aquinas (1225-1274) ve Duns Scotus (1265-1308) gibi Hristiyan düşünürler tarafından geliştirilmiştir.

İslam düşüncesinde ise etiğin gelişiminde rol oynayan iki ana kaynaktan söz etmek gerekir. Bunlar Allah'1n, kullarına vahyini ilettiği Kur'an-1 Kerim ve Peygamberin sünnetidir. Temelde İslam ahlakının ana kaynağı ve asli referansı olarak vahiy esas alınır. Allah, kullarına "iyi" ve "kötü"ye dair bilgisini iletmiş ve neyi yapmaları, neden uzak durmaları gerektiğini Kur'an'da bildirmiştir. İnsan için Kitapta belirtilen hususların, aksi anlama gelecek şekilde ya da Tanrı'nın amacının dışında bir gayeye hizmet edecek biçimde yorumlanması mümkün değildir. Burada belirtilen hususlar iman meseleleri olarak kabul edilir ve bu hususlara itaat imanın göstergesidir. Allah, vahyi aracılığıyla geçmiş ümmetlerin yapıp etmelerinden örnekler göstererek ahlaki olan ve olmayanı somut örnekler üzerinden kullarına bildirmiştir. Kur'an'da yer alan örnek hadiselerin çeşitliliği ve çokluğu Allah'ın vahyinin, kullarının hayatlarını topyekün olarak kapsadığını göstermesi bakımından önemlidir. Böylelikle Allah kulları için hangi durumlarda nasıl bir tavır ortaya koyulması gerektiğine dair temel ilkeleri vaz etmiş ve bu temel ilkeler 1şı̆̆ında kendilerine has özel durumlara ilişkin sağlıklı kararlar alabilmelerine yardımcı olmuştur.

İslam düşüncesinde ahlaki, dini ve sosyal hayatın merkezinde yer alan Kur'an, her ne kadar İslami prensiplerin tümünü içerse de teknik anlamda bir ahlak teorisi sunmaz. Bu nedenle bu prensiplerin açığa çıkarılması gerektiği İslam ahlak araştırmacılarının dikkatini çekmiştir. Macit Fahri, İslam ahlak teorilerini nassî, kelâmî, felsefi ve dini olmak üzere dört grupta inceler. Konumuzla ilgili olarak, ona göre dini ahlakın temel unsurları, Kur'ânî dünya görüşü, kelâmî kavramlar, felsefi kategoriler ve bazı durumlarda tasavvuftur. Bu nedenle bu ahlak sistemi hem en karmaşık hem de en tipik dini etik teori olarak karşımıza çıkar (Fahri, 2018, s. 28-29). İslam düşüncesinde dini etik teorilere Maverdî (ö.1058), 
İsfehâni (ö.1108), Gazzâli (ö.1111) ve Fahreddin Râzi (ö.1209)'nin etik teorileri örnek olarak gösterilebilir.

\section{Gazzâlî’nin Dini Etik Teorisi}

Dini etik teorilerin tipik bir örmeği olarak Gazzâlî’nin etik teorisi, felsefi, kelami ve sûfi ahlakını bir araya getirir ve şüphesiz İslam düşüncesinde dini etik teorilerin en önemli temsilcisidir. İslam düşüncesinde ahlaki değerlerin kaynağı genellikle hüsün kubuh meselesi başlığ 1 altında tartışılır ve Eş'arî bir kelamcı olarak Gazzâlî, el-Mustasfa adlı eserinde, bu konuya müstakil olarak yer verir (Gazzâlî, 1994, s. 74-75). Ahlaki değerlerin kaynağını Tanrı'nın iradesi ile izah eden Gazzâlî̀ye göre, öncelikle "iyi" ve "kötü", insanlar için, varlıkların sıfatları değil, ihtiyaca ve içinde bulunulan şartlara göre değişen göreceli durumlardır. İkinci olarak "iyi” ve "kötü" zaruri olarak akıl tarafından bilinebilecek olsayd1, bu konular insanların sürekli tartıştı̆̆ konular olmazd1. Son olarak, biz akıl sahibi kimselerin bir konuda ittifak ettiklerini kabul etsek bile, bu ittifak çirkinliğin zarûriliği lehine bir delil olmaz; akıllıların bunu kabul etmek zorunda oldukları söylenemez. Gerçekte bu ittifakın zaruri olmayan bir şey üzerinde meydana gelmesi de mümkündür. Nitekim insanlar yaratıcının ispatı ve peygamber göndermenin cevazı hakkında ittifak etmiş, çok az kimse buna muhalefet etmiştir. Şayet bu azınlık da diğerlerinin fikrine katılmak suretiyle onlarla ittifak etselerdi, bu husus yine de zaruri olmazdı (Gazzâlî, 1994, s. 76). Genel hatlarıyla Gazzâlî’nin ahlak öğretisinde bir dine inanmaksızın veya belli amaçlar taşımaksızın "iyi” ve "kötü” hakkında kanaat sahibi olunamayacağı anlaşılsa da "hüsün”ü Allah'ın tüm fiillerinin bir vasfi, "kubuh"u ise tüm mezheplere göre "hasen"in zıddı olarak tarif ederken ahlâkî değerler konusunda mutlak bir rölativizmi savunmadığı, aksine dini, ahlâkî değerlerin objektif bir kriteri olarak konumlandırdığ görülmektedir (Korkmazgöz, 2015, s. 52).

Aynı zamanda tasavvufi ahlakın da önemli temsilcilerinden kabul edilen Gazzâlî, Müslümanlar için gündelik hayatın rehber kitabı olarak değerlendirilen eseri İhyâ 'u Ulûmid-Din'de ahlaktan dini bir ilim olarak bahseder (Gazzâlî, 1974, s. 174). Gazzâlî bu eserde, dünya hayatını, sonunda hüküm gününün bulunduğu bir imtihan yeri olarak tasvir eder. İrade ve eylemin önemine dikkat çeken Gazzâlî, iyi inançtan çok iyi eyleme vurgu yapar ve bir Müslüman için iyi ve doğru eylemin ifasının, ancak ahlakı Kur'an ahlakı olan Hz. Muhammed'i taklit etmekle mümkün olacağını ifade eder. Gazzâlî’nin, Hz. Peygamberin "Allah'ın ahlakı ile ahlaklanın" tavsiyesini açıklamak amacıyla kaleme aldığını ifade ettiği Esma-i Hüsnâ Şerhi'nde kulun, Allah'ın sıfatlarından mümkün olanları elde etmeye onunla ahlaklanmaya onun güzellikleri ile nefsini tezyin etmeye çalıştı̆̆ından söz eder (Gazzâlî, 2005, s. 4344).

Kur'an'ın muhtevası incelendiğinde de görülür ki, Kur'an hayatın her alanı ile ilgili prensipler belirler. $\mathrm{O}$ hem dünya hem ahiret hayatını gözetir. Onda inançla ilgili açıklamalar olduğu gibi, ibadet ve sosyal hayatla ilgili ölçüler de vardır. Bu ölçüler, birbirlerinden ayrılmaz bir şekilde iç içe bir örgü olarak sunulmuştur. Sözgelimi, pek çok ayette sosyal hayatla ilgili prensipler Allah ve ahiret hatırlatması ile son bulurlar. Kur'an'da bir hukuk kitabı gibi, şunlar yasaktır, bunlar serbesttir şeklinde yalın ve donuk ifadeler bulunmaz. Kur'anî prensipler dünya-ahiret, inanç-eylem, ruh-şekil bütünlüğü içerisinde verilir. İște bu yüzden Kur'an ahlakı bunların hepsidir. Kur'anî ölçütlerin hepsi bir sistemi oluştururlar. Bu sistemin parçalarından birinin eksikliği, ahlaki bir eksikliktir: Kâmil bir ahlak, ancak bütünüyle Kur'an ile mümkün olacaktır. İşte ahlak, bunların hepsidir (Akpınar, 2001, s. 66). Gerek Kur'an'da yer alan ifadeler gerek İslam düşünürlerinin yaklaşımları ahlakın vahiyden bağımsız olamayacağına işaret etmektedir. $\mathrm{Bu}$ noktada etik, dinden türeyen ve dini yaşantıyı ifade eden bir kavram olarak algılanmıştır. Bu yönüyle vahiyden referans alan etiğin pratik mahiyeti peygamber aracılığı ile de her kademe akıl için somutlaşma imkânına sahip olmuştur.

\section{Kant'ın Ödev Etiği}

Ahlakın dine dayalı olarak düşünülmesinin bir yolunu da Kant'ın ödev etiğinde görmek mümkündür. Kant'a göre, bir eylemin ahlaki açıdan iyi olması için, ahlak kurallarına uygun olması yeterli değildir; aynı zamanda yasaya da uygun olmalıdır. İyiyi istemeden başka kendi başına iyi olarak nitelendirilebilecek bir şey düşünülemez. Akıl, zekâ, yargılama ve zihnin diğer yetenekleri gibi cesaret, karar, azim türünden nitelikleri, kuşkusuz pek çok açıdan iyi ve arzu edilir; ama bunları 
kullanan irade iyi değilse, bunlar son derece kötü olabilir. Ahlaki olarak adlandırdığımız üstün iyilik, iradenin belirlediği ölçüde, yasa kavramının kendisinden başka bir şey içermez.

$\mathrm{O}$ halde ne tür bir yasa ya da beklenti bundan beklenen etkiyi göz önünde bulundurmaksızın iradeyi belirler? Ona uymaktan doğacak her türlü dürtü iradeyi herhangi bir başka etki altında kalmaktan koruduğu için, genel olarak geriye hukukun eylemlerine uygunluğundan başka bir şey kalmaz, yani, hiçbir zaman başka türlü davranamam. Böylelikle kişinin amacı evrensel bir yasa haline gelmeli. Burada genel olarak iradeye hizmet eden yasanın uygunluğu aranır. İnsanların pratik yargılarındaki ortak gerekçe, bununla mükemmel bir şekilde örtüşmekte ve her zaman burada öne sürülen ilke göz önünde bulundurulmaktadır. İnsanın ahlaklı eylemlerindeki akıl ilkesi, bir buyruk, gereklilik gösteren bir ilke niteliği taşır.

Kant kendine has bir tür akıl yürütme ile, düşünce ile davranış arasındaki tutarlılığı belirleyebilecek bir kriter geliştirmeye çalıșır. Ancak onun söz ettiği "düşünce" daima kendi iradesini kullanabilen akıl sahibi bir varlık olarak insan düşüncesine işaret etmektedir. Buna göre, örneğin şunu sorar: "Zor durumda kaldığımda tutmamak niyetiyle bir söz verebilir miyim?" (Kant, 2015, s. 17). Sorunun içerdiği iki ihtimali hemen ortaya koyalım: yanlış bir söz vermek, ihtiyatlılık mıdır, yoksa doğru mudur? Sadakatsizliği göze alarak ihtiyatlı davranmak benim için kesinlikle avantajlı olsa da yasaya uymak daha doğru ve güvenli olanıdır. Yanlış bir vaadin ödevle tutarlı olup olmadığını keşfetmenin en kısa yolu kendime şunu sormaktır: "Benim yasamın kendim için olduğu kadar, başkaları için de evrensel bir yasa olduğundan emin miyim?" ve kendime şunu söyleyebilmeliyim, "Kendini kurtarmanın bir başka yolunun olmadı̆̆ bir durumda herkes yalan söyleyebilir mi?" Demek ki yalan söyleyebildiğim halde, evrensel bir yasa olması nedeniyle yalan söyleyemem.

Kant'a göre, irademin ahlaki açıdan iyi olması için ne yapmam gerektiğini anlamak için geniş kapsamlı bir araştırmaya ihtiyacım yoktur. Hayat boyunca deneyimlenmemiş, tüm olasılıklar için hazırlıksız olarak, şunu sorabilirim: Maksiminizin evrensel bir yasa olması gerekmez mi? Eğer değilse, o zaman, kendisine ya da başkalarına karşı bir dezavantaj nedeniyle değil, fakat olası bir evrensel yasaya ilke olarak uygun olmadığı için ve buna olduğu gibi saygı duymam gerektiği için maksiminiz reddedilmeli. Pratik hukukun tam anlamıla saygılı davranmayı içermesi, her diğer dürtünün de yer alması gereken görevi oluşturan şeydir, çünkü o, kendi içinde iyi olan bir iradenin şartıdır ve böyle bir iradenin değeri her şeyden yüksektir.

Objektif bir ilke, zorunlu olduğu ölçüde, bir buyruk olarak adlandırılır ve buyruğun formülü bir zorunluluk ifade eder. Tüm zorunluluklar, bir buyrukla ifade edilir ve objektif bir hukuk yasasının, mutlaka onun belirlediği bir irade ile ilişkisini gösterir. Şimdi tüm zorunlu buyruklar ya hipotetik ya da kategoriktir. Birincisi, muhtemel bir eylemin pratik zorunluluğunu, istendiği başka bir şey için araç olarak temsil etmektedir. Kategorik zorunluluk, objektif olarak gerekli olduğu gibi, başka bir sonuca atıfta bulunmaksızın, kendi başına gerekli olan bir eylemi temsil eder. Kategorik bir zorunluluk, belirli bir davranışın ifasını, kendisi tarafından elde edilmesi için başka herhangi bir amaç gütmeksizin buyurur. İşte bu zorunluluk ahlaka isim olabilir. Bir temel kategorik zorunluluk vardır: sadece o anda yapabileceğiniz maksimi harekete geçirin, o aynı zamanda evrensel bir yasa haline gelecektir.

Akılcı bir varlık olarak insan, şu ya da bu irade tarafından keyfi olarak kullanılan bir araç olarak değil yalnızca kendi başına bir amaç olarak vardır. Akıl sahibi olmayan varlıklara, araç olarak yalnızca göreceli bir değere sahip olduklarından "şeyler" denir; akıl sahibi varlıklar ise amaçları kendinde son bulan olmalarından dolayı "kişiler" olarak adlandırılır. Şeyler bir araç olarak görülür ve kullanılırlar; fakat kişiler, bizim için daima en yüksek saygının objesi olmalıdır. İnsanlara saygı duyma ödevime göre, hiç kimseyi amaçlarım için bir araç olarak görmemeli ve kullanmamalıyım, kimseyi böyle bir dereceye indirmemeliyim. Ona göre her kişi objektif bir amaçtır. İnsan istemelerini yöneten, ahlaklı istemeyi belirleyen objektif amaçlardır.

O halde eğer kategorik bir zorunluluk varsa, kendinde bir gaye olmasından ötürü herkes için geçerli bir gayeden çıkarılmalıdır. Mesele şu ki rasyonel doğanın kendisi bir gaye olarak vardır. Bu nedenle eylemin sübjektif bir ilkesi olduğu için kendi varlığımı bu şekilde düşünmeliyim. Fakat diğer her rasyonel varlık da varlığını benzer şekilde kabul ettiği için aynı zamanda bu objektif bir ilkedir. Buna göre, pratik zorunluluk şu şekilde olacaktır: İnsanlığa, her zaman ve her durumda bir araç olarak değil, 
sadece ve sadece kendi başına bir amaç olarak davranmalısın. İnsan rasyonel bir varlık olarak bu "yapmalısın" buyruğunu kendi içinde bulur.

Kant, ahlak yasasını, istememizin maksimi yapan şeyin saygı duygusu olduğundan bahseder. O, insanın tüm eylemlerinde insan olmanın onurunu hesaba katması gerektiğini ve bunun son ölçü olduğunu söyler. Kant, ahlak yasasından insanları birbirine bağlayan dindarane bir saygı ile söz eder. Onun ahlak yasasında yer verdiği bu derin duygunun ancak metafizik bir motif ile açıklanabileceği görülmektedir. Zira Kant insanın bütün dünyevi araçsal eğilimlerden, hazlardan sıyrılıp koşulsuz olarak bu yasaya boyun eğmesini ister. Hatta Kant, bu boyun eğmeği ileri götürerek, dişsal bir zorlama içermeyen bu tutumun, insanın lezzetine doyamayacağı bir yücelik taşıdığını düşünür.

\section{Ödev Etiğinde Postulatların Fonksiyonu}

Bu noktadan itibaren Kant'ın ödev etiğinin salt pratik aklın postulatları ile ilişkisi devreye girmektedir. Zira Kant'a göre insan akl1, sadece fiziksel dünyada tecrübe ettiklerini kavrayıp onunla teoriler kuran teorik bir akıl değildir. Aklın insanın ne yapması gerektiği konusunda kendisinde birtakım bilgiler barındıran bir yönü de vardır ki Kant bu aklı salt pratik akıl olarak tanımlar. Burada, Kant'ın inanca yer açmak için bilgiyi kaldırmak zorunda kalmasını, pratik akla açmak istediği alanı göz önünde bulundurarak ifade ettiği anlaşılmaktadır. Ahlak bilgisinin buyruklarının yerine getirilmesinde salt pratik aklın taşıdığı açıklık ve kesinlik Kant'ın çok önem verdiği bir konudur. Kant'ın "inanca yer bulmak için bilgiyi inkâr etmesi" dogmatizmi ve septisizmi yıkmaya yöneliktir (Demirtaş, 2013, s. 292).

Kant'a göre teorik akıl bize "olan1," pratik akıl ise "olması gerekeni” bildirir. Kant, özgürlük, ruh ve Tanrı gibi metafizik kavramların bilgisinin sadece saf akıl ile bilinemeyeceğini iddia ederek, bu anlamda bir fizik ötesinin imkânını reddetmiştir. Ona göre akıl, sadece fenomenleri bilir ve bütün işlemlerinin maddesini sadece duyarlılıktan alır. Oysa Tanrı ve ruh gibi ideler, fenomen değildir ve duyarlılıktan gelen içerikleri yoktur. Buna karşın Kant bu kavramların reddedilmesine karşı çıkar. Bu kavramlar "pratik aklın" postulatlarıdırlar. Kant böylece bu kavramları bilgi alanından ahlak alanına taşıyarak ve sahip oldukları alanları da matematik postulatlar tarzında kabul ederek bu kavramlara inanmanın rasyonel olduğunu ortaya koymak istemiştir. Kant'ın ödev etiğinin de üzerine bina edildiği bu postulatlar, insanın özgürlüğü, ruhun ölmezliği ve Tanrı'nın varlığıdır. Ona göre bu ideler ancak pratik aklın devreye girmesiyle bilinir hale gelebilir.

Insanın Özgürlüğ̈: Kant insanın, duyuşsal ve deneysel özelliklerine uygun biçimde numen-fenomen ayrımı yaparak, teorik bakımdan bu her iki alanın ilkelerine ait bilginin, insanın özgür eylemleri sayesinde uyumlu bir şekilde kullanıldığına işaret eder. İnsan ancak özgürlüğü sayesinde aklın idelerini kullanabilir ve yasalar koyabilir. Bu esnada duyular dünyasının nedensellik ilkelerine de bağlı olarak hareket etmeye devam eder. Kant numen - fenomen ayrımı yapmakla birlikte insanı bu her iki dünyanın bir parçası olarak tasvir etmeyi göz ardı etmez. Kant eylemlerini belirleyen insandan, koşullara bağlı olmaktan kendisini kurtarıp mutlak olana yönelmek suretiyle kararlar alabilmesini ister. Ona göre bu tür bir karar alabilmesi için insan, ona sürekli olarak "yapmalısın" diye seslenen buyruğa kulak vermelidir. Bu ses onun özgür bir varlık olduğunun göstergesidir. Zira böyle bir buyruğun olması onun özgür olduğunun dolayısıyla eylemini gerçekleştirip gerçekleştirmeme konusunda son kararın kendisine ait olduğunun kanıtıdır.

Kant'a göre özgürlük ve ahlak yasaları birbirlerini temellendirir. Pratik akıl, ahlak yasası için özgürlüğ̈u zorunlu kılar. Özgürlük idesine uymaktan başka türlü hareket edemeyen her varlık pratik anlamda gerçekten özgürdür. Kant bu noktada özgürlüğün her tür yasadan bağımsız olarak algılanmasına karşı çıkar, zira gerçek özgürlük insanın yasaya, kendi iradesinin öz yasasına uymasıdır. Bu nedenle Kant, pratik akla inanca yer açmak için bilgiyi inkâr etmek durumunda kalmıştır. Kant'ın inkâr ettiği bilgi, onu özgürce düşünmekten ve kendi öz yasalarına uymaktan alıkoyan bilgidir. İşte Kant'ın postulat adını verdiği bu inancın ilk basamağı insan özgürlüğüne olan inançtır. Çünkü özgür insan, inanmak, düşünmek ve eylemek için en önemli gücü elinde bulunduran insandır.

Tanrı'nın varlı̆̆ı: Kant, en yüksek iyinin gerekli koşulu olarak, evreni yaratan, yani varlığının bir nedeni olmayan ve kendisi diğer her şeyin nedeni olan Tanrı postulatından söz eder. Ona göre dünyada en yükssek iyinin var olması için insanın doğada ahlaka uygun bir gücün var olduğunu kabul etmesi 
zorunludur. Tanrı bir anlama yeteneği ve irade olarak, evrenin bütününü yönetmesi; mutluluğa yaraşır olma ve mutlu olmayı bir araya getirmesi bakımından vardır (Heimsoeth, 2012, s. 138). Tanr1, "iyi"nin biricik modelidir. Kant, en üstün iyi olarak "Tanrı" kavramının bize, aklın ahlaksal yetkinlik konusunda kurduğu ve özgür bir isteme kavramına ayrılmazcasına bağladığ1 "ide"den geldiğini söyler (Kant, 2015, s. 25). Kant bu postulatın yokluğunun, eylemin ahlaksal denetiminin ortadan kalkmasına neden olacağına işaret eder. Çünkü ona göre, eğer bir en yüksek ahlaklılık ilkesi yoksa sergilenen eylemin iyi olup olmamasını sorgulamak yersiz olacaktır.

Akıl sahibi varlık olarak yalnızca insan, eylemlerini seçerken, belirlerken ve uygularken yasalara uygunluğu dikkate alabilir. Yasadan eylem türetmek için akıl gerekli olduğundan isteme pratik akıldan başka bir şey değildir. Dolayısıyla isteme, eğilimlerden bağımsız olarak ancak aklın pratik bakımdan zorunlu, yani iyi olduğunu bildiği şeyi seçme yetisidir. Bu nedenle ödev etiğinde iyi isteme Tanrı postulatını zorunlu kılar. Zaten Kant ahlaklı bir hareketin saf ve temiz olabilmesi için eylemin arkasında yatan niyeti bilen bir vicdanın var olması gerektiğinden bahsederken yukarıda bahsettiğimiz bilgiyi inkâr meselesine de açıklık getirmektedir. Yani Kant, pratik akla inanca yer açmak için, teorik aklın bilgisini ya da fenomen dünyaya ait bilgiyi inkâr etmek durumunda kaldığından söz etmişti. Böylelikle onun yapmak istediği, salt aklın pratik bilgilerine, inanca yer açmaktır. Kant'ın ahlak yasası, bütün eylemlerimizde yasaya uygunluk aramaktadır. Yasanın dışında hiçbir etkenin zihni meşgul etmemesi ya da etki altında bırakmaması gerekir. Bu nedenle yasaya ve ona olan inanca yer açmak için zihni meşgul eden diğer bilgilerin, duyguların ve arzuların bizi yönlendirmesinden kendimizi kurtarmak zorundayızdır. Tabiatıyla, bir iman konusu olarak Tanrı'nın, gözlenebilir, sınanabilir bir alanın dâhilinde olduğu iddia kabul edilemez. Tanrı, duyusal olarak algılanabilir bir nesne değildir. Ne yaparsak yapalım, Tanrı pozitif bir deneyin nesnesi olamaz. Tanrı kavramı fiziğe değil ahlaka ait bir kavramdır (Kant, 1994, s. 152).

Kant, Tanrı'yı, salt bir konumlamayı da aşarak tam anlamıyla bir imkân olarak inanç üzerine doğrular. Aslında onun yaptığı bir bakıma erdem ve mutluluğu birleştirmek amacıyla Tanrı'yı bir araç olarak konumlandırmaktır. O "Salt Aklın Sinırları İçerisindeki Din" adlı eserinde gerçek anlamda bir dinden söz etmez. O dindar bir kimse için derin bir Tanrı gereksiniminin farkındadır ve bu duygunun insanı kişisel bir Tanrı fikrine götürdüğünü düşünür (Copleston, 2010, s. 154).

Ruhun Ölmezliği: Kant'a göre gerçek bir varlık olmayan ruh, özü itibariyle yalnızca sonsuz olan bir idedir. Kant'a göre, Platon, ideleri sonsuzlukta bulunan gerçek varlıklar olarak tanımlarken hata yapmıştır (Akarsu, 2014, 38). Zira yapılan şey bilgi için sonlu bir ödev belirlemek oluyordu. Kant'a göre ise bilginin sınırları sonsuza değin açı olmalıydı. Bu sayede Tanrı ve özgürlük postulatlarında olduğu gibi ruh hakkındaki postulat da kaynağını aklın ahlak bakımından olan umut ve beklentilerinde bulması için uygun olmalıydı (Heimsoeth, 2012, s. 141).

Kant, ahlaksal eksiksizlik için çaba göstermekle yükümlü olduğumuzu ve bu eksiksizliğe de sonlu bir zaman içerisinde erişilemeyeceğini düşünmektedir. Ahlaksal eksiksizliği arama ya da ahlak yasasına uyma yükümlülüğü sürekli olarak ona yönelik eylemde bulunulması için motive eder. Dolayısıyla arzu ve hislerin, aklın egemenliği altında tam uyumu için sonsuza dek çabalamak gerekecektir (Copleston, 2004, s. 146-147). Bu nedenle Kant, ruhun ölmezliğini, sınırlı ve sonlu olan hayatta ahlak yasasına tam olarak uygun bir yaşam sürmenin zorunlu koşulu olarak görür. Ona göre bütün eylemlerinde ahlak yasasına uygunluk, ancak üstün ya da kutsal bir varlığın başarabileceği bir şeydir. Bu ise ahlaki varlık olarak sadece insanın üstesinden gelebileceği bir durumdur. Her ne kadar üstesinden gelinmesi zor olarak görünse de uğruna çaba sarf edilmeye en fazla değecek şey insan için böyle bir idealdir. $\mathrm{Bu}$ insan için aynı zamanda en yüksek mutluluktur. Bu nedenle insanın en yüksek tamlığa ulaşması için ancak sonsuza kadar devam eden bir oluş zorunludur. Kant'ın ruhun ölümsüzlüğüne dair görüşü teorik bir gerekliliğin ötesinde ahlaklı istemenin, yüksek niyetlerin ve çabaların gerçekleştirilmesine imkân tanınmasının beklentisidir. Kant'ın ödev etiğinin temelinde yer alan bu üç postulat aslında dini etiğin de temel kavramlarıdır. Zira Kant'ın, ahlak yasası için kendine has olarak geliştirdiğini iddia ettiği postulatların dini birtakım kavramlara dayandırıldığı ve nihai olarak yine dini etiğin referanslarını kullandığı anlaşılmaktadır. 


\section{Ödev Etiği Dini Etik İlişkisi}

Kant'a göre, melekelerimizin başında ve eşyanın en yukarısında bulunan akıl değil, iradedir. O, aklın, ortaya çıkması engellenemeyen antinomilere sürekli çarparak şüphe içine düşebildiği halde iradenin inancın müttefiki, ahlaki ve dini eğilimlerimizin de kaynağı olduğuna inanır. Kant hiçbir şekilde Tanrı'yı inkâr etmez, sadece bu idenin realitesini kanıtlamanın akıl yürütmeyle mümkün olmadığını savunur (Weber, 1998, s. 322). Aslında Kant, metafiziğin insan için doğal bir istidat olduğunu ve bu nedenle insanın yapısının, insanı duyular üstünü düşünmeye zorladığını savunur. Metafiziğe dair Kant'ı farklı yapan görüş ise bu noktadan itibaren ortaya çıkıyor. Kant, bilimsel nitelikli metafiziğe karşıdır. Onun hedeflediği metafizik akıl bakımından zorunlu ve pratik akılla temellendirilmiş bir metafiziktir (Gökberk, 1999, s. 359-360). Diğer taraftan Kant'nn metafizik ile kast ettiği "apriori"dir yani bilgide de yalnız apriori olan ile ilgilenen Kant'ın ahlakta da apriori olanı araması kesin olan bir ahlak bilgisine varmayı göz önünde bulundurmasındandır. Böylelikle Kant, ahlak alanında da şayet bir apriori varsa, o zaman bilimsel nitelikli bir ahlak teorisinden söz edilmesinin yolunu açmak ister. Bundan sonra eylemlerin ahlaki niteliği onların apriori olmalarında aranır, yoksa içgüdü, eğilim ve eylemlerimizin sonuçlarında değil (Gökberk, 1999, s. 360).

Kant'ın ödev etiğinin üç postulatı aynı zamanda, onun etik anlayışının dini etik ile benzer ve farklı yönlerine dair fikirler vermektedir. Dini etik, insandan Tanrı tarafindan gönderilen ahlak yasasına tam bir teslimiyetle itaat etmesini ister. Kant'ın ödev etiğinde ise ahlak yasasına uyma temayülü dişsal bir motivi aşar. Ona göre insan ahlak yasasına uymak konusunda özgürdür ve bu özgürlük zorunlu olarak ahlaki bir varlık olan insanın bu yasaya uymasını gerektirir. Kant'ın ahlak yasasının temel kavramlarından olan özgürlük, ahlaki eylem için zorunlu önkoşuldur. Zira insanın, bilerek isteyerek ve başka hiçbir dışsal motive edici etkiden ya da arzu ve beklentilerini tetikleyecek etkenlerden arınmış bir duygu ile eylemini seçmesi gerekmektedir; Tanrı gibi dışsal bir etkenin emri gereği olarak değil. Eylemin sonuçlarının hesaba katılması ile ortaya çıkan fayda-zarar beklentileri eylemin özgürce ortaya konmasını engellemektedir. İyi davranışın ödüllendirilmesi ya da kötü davranışın cezalandırılmasına dair bir talimat, emir ya da bilgi, insanın özgür seçiminin ortadan kalkmasına neden olmaktadır. Kant vahye dayalı ahlak yasasına itibar etmez. Ona göre salt pratik aklın kendi yasalarına uygun olarak ortaya koyduğu eylemler ahlaki eylemlerdir. Bu nedenle dini etikte evrensel ahlak yasasının kaynağı Tanrısal buyruklar iken Kant'ın ödev etiğinde ahlak yasasının kaynağı ahlaki bir varlık olarak insanın kendisidir. Kant, bütün ahlak kavramlarının yerinin ve kaynağının tamamen apriori olarak akılda bulunduğunu savunur (Kant, 2015, s. 27).

Kant'ın etiğinde işaret edilen "ödev" kavramı, insana insan olması bakımından tabiatına uygun davranma yükümlülüğünü hatırlatır. Tabiatı gereği akıl sahibi olan insan için, eylemlerinde aklın rehberliğinin görmezden gelinemez olduğunu anlatmak ister. Kant bir bakıma ödevin, Tanrı'nın hatırlatmasına gerek kalmaksızın, akıl sahibi insanın yapması gerekeni bizzat kendi bilgisi ile bilinçli olarak ve arzu ederek yapması gerektiğinden bahseder. Aslında Tanrı'nın irade ettiğinin ahlaka uygun olduğunu bilen ve kabul eden Kant, bu niyetin ve eylemin Tanrı'nın irade etmesinden önce insanın bizzat kendisi tarafından ortaya konulmasını gerçek anlamda etiğe uygun bulur. Bu nedenle Kant'ın ödev etiği ideal bir teori olarak değerlendirilebilir ancak pratikte, işler Kant'ın istediği gibi gitmeyebilir. Bu noktada dini etiğin fonksiyonu devreye girer ve Kant'in idealinde de yer alan "herkesin isteyebileceği faydayı gözeten kurallardan" söz eder. Zira dini etik tüm kâinatı yaratan dolayısıyla mutlak bilgi ve güç sahibi olan Tanrı'nın iradesinden doğmaktadır. Bu noktada Kuçuradi, Kant'ın ölçütlerinin insanın eylemlerinin doğru olmasının tek başına sağlamaya yetmeyeceğine dikkat çeker. Ona göre, kişi bu ölçütlerle kendisini kurtarabildiği halde bilmeden istemeden başkalarının zararına olabilecek kararlar alma durumu halen söz konusudur. Ayrıca bu durumda kişinin bilmesi gerektiği halde bilmesi gerekenlerden de sorumlu olduğu göz ard1 edilmiş olur (Kuçuradi, 2018, s. 68).

Aslına bakılırsa Kant, dini etiğin buyurucu karakterinin eylemin özgürlüğünü kısıtladığını düşünür. Ancak hemen hemen tüm dinlerin ahlak düşüncesinde, başlangıçta doğru eylemleri taklit ederek öğrenen insanların hayatlarının belli bir döneminden sonra içselleştirmeleri gerektiği öngörülür. Ayrıca bu yaklaşım, eylemin özgür kılınması için şart olarak kabul edilmektedir. Bir örnek olarak, Kant'ın ödev etiğinin, İslam düşüncesinde en bariz bir şekilde Gazzâlî'de ifadesini bulan "tahkiki iman" ile mümkün olacağı söylenebilir ki bu her mümin için zorunlu olarak kabul edilir. Bu anlamda 
dini etiğin özü, en azından İslam düşüncesinde, eylemlerin bilinçli ve kasıtlı olarak yapılmasını; bilerek ve isteyerek ifa edilmesini talep eder. Dolayısıyla taklidi düzeyde kalarak içselleşmemiş olan, zoraki bir dayatma ile gerçekleşen ve bir bakıma uyum vesilesi olarak görülen eylemi dini etik de doğru bulmaz.

Bu bakımdan Kant'ın ödev etiği, dini etikten pek de ayrı durmamaktadır. Onun yaptığı, Tanrı'nın yerine aklı, ilahi buyruk yerine ahlak yasasını, Tanrı'ya itaat eden kulun yerine akla itaat eden bireyi, cennetin yerine en yüksek iyiyi, Tanrı'nın krallığı yerine evrensel saf akıl dinini/etik devleti/hakiki kiliseyi koyarak, dini etiği seküler bir dille ifade etmek olarak görülmektedir (Tüzer, 2015, s. 142143). Benzer bir fikre sahip olan Nuyen'e göre de Kant, "her yasanın bir yasa koyucusu vardır" ve "ahlak yasasının yasa koyucusu zorunlu olarak Tanrı'dır" öncüllerini ifade etmek suretiyle hem ahlaki değerlerin kaynağını Tanrı olarak göstermekte hem de Tanrı'ya dayalı değerlerin nesnelliğine işaret etmektedir (Nuyen, 1998, s. 446). Aynı şekilde Kant'ın Saf Aklın Sinırları İçerisinde Din adlı eserinde, dini etiği andıran çok sayıda ifadesi ile karşılaşmaktayız: Kant, ahlaki dine dair düşüncelerini ifade ederken, "kalplerin, Tanrı'nın emirleri gibi tüm insani ödevleri yerine getirmeye yatkın (Kant, 2017, s. 105)" oluşundan bahseder. Kant, aynı yerde, "insanların birbirlerine karşı ödevlerini yerine getirdiklerinde böylelikle Tanr'nın emirlerini de yerine getirdiklerini (Kant, 2017, s. 123)" söylüyor. "Tanrı'ya olan saygının özü, tüm buyruklara O'nun buyruklarıymış gibi itaat etmektir" diyerek sonunda, dinin biraz farklı bir tanımına ulaşıyor: "Din tüm ödevlerin Tanrı'nın emirleri olarak kabul edilmesidir (Kant, 2017, s. 124)".

Kant ikinci eleştirisi Patik Aklın Kritiğinde de ödev etiğine ilişkin düşüncelerini dini etiğe referans olarak alınabilecek ifadelerle açıklamaya devam eder: "Yaratıcı eyleminde Tanrı, bir yasa koyucuyla aynı şekilde bir yasa tasarısını yürürlüğe sokar. Belli bir gerçeklikle var olduğu söylenen bir yasalar bütünü oluşturur. Tanrı, emirleri aracılığıyla ahlakın mümkün olabileceği mantıksal zemini yaratır (Nuyen, 1998, s. 449)". Ancak Tanrı, ahlakın mantıksal zemini olsa da "düşüncemizin bir fikri olarak ahlaka bağlıdır." Bu anlamda Kant, "ahlak, dinin bilinme sebebidir" şeklinde okunabilir. Hatta bu nedenle Nuyen, din ve ahlakın karşılıklı bağımlılı̆̆ının Kantçı bir çerçeveden çıkmış olabileceğini iddia eder: ona göre, Tanrı ile ahlak arasındaki ilişki asimetriktir: Tanrı, özgürlük ve yasa için mantıksal zemini yarattı̆̆ için hem ahlakın varlık nedenidir, buna karşılık kendi kendine karar veren olmadığ 1 için ahlakın kendinde nedeni olamaz; hem de ahlak dinin bilinmesinin nedenidir, fakat buna karşı1ık da ahlak yalnız akılla bilinebilir olduğu için dinin tek bilinme nedeni değildir (Nuyen, 1998, s. 450).

Kant'ın ödev etiği ile onun Tanrı'nın emirlerine yüklediği anlamın dini etiği çağrıştıran başka örnek ifadeleri de vardır. Kant Pratik Aklın Kritiğinde ahlak yasası hakkında şöyle söyler:
“Ahlak yasası, bana bir dünyada olanaklı en yüksek iyiyi, her türlü davranışımın en son nesnesi yapmamı buyurur. Böyle bir şeyi de ancak istememin, kutsal ve iyilik dolu bir yaratıcının istemesiyle uyuştuğunda gerçekleştirmeyi umabilirim. Bu yüzden ahlak da aslında kendimizi nasıl mutlu kılacağımızın öğretisi değil, mutluluğa nasıl lâyık olmamız gerektiğinin öğretisidir. Ancak din de işin içine katıldığında mutluluğa lâyık olmama durumuna düşmekten sakındığımız ölçüde günün birinde mutluluktan pay almamız umudu doğar (Kant, 1994, s. 140-141)”.

Kant, aynı yerde, insanın mutluluğa ulaşma koşulu olarak, ona layık olma şartını dile getirirken bilge bir yaratıcıdan bahseder. Ona göre bilgelik;

“...teorik olarak ele alındığında en yüksek iyinin bilgisi, pratik olarak ele alındığında ise istemenin en yüksek iyiye uygunluğu anlamına geldiğinden, en yüksek bağımsız bir bilgeliğe, yalnızca iyilik üzerinde temellenen bir amaç yüklenemez. Nitekim bu iyiliğin en yüksek aslî iyiye uygunluğu, ancak O'nun istemesinin kutsallığıyla uyuşmanın sınırlayıcı koşulları altında düşünülebilir, işte bundandır ki yaratmanın amacını Tanrı'nın onurlandırılmasında görenler en uygun ifadeyi kullanmışlardır. Çünkü insanların, dünyada en değerli şey olan, Tanrı buyruğuna saygı göstermeleri ve Tanrı yasasının bize yüklediği kutsal ödevi gözetmelerinden başka hiçbir şey Tanrı'yı daha çok onurlandıramaz. Bu mutlulukla 
taçlandırma Tanrı'yı sevilmeye değer yaparken, buyruğuna saygı duyma da O'nu ibadete layık k1lar (Kant, 1994, s. 142)".

Kant'ın ödev etiğinde Tanrı'nın varlığı vazgeçilmez önkoşul haline gelir. Zira dünyada bu en yüksek iyinin var olması ancak doğada "ahlaka uygun bir gücün" en yüksek neden olarak var olduğunun kabul edilmesi ile mümkündür. Böyle bir varlığa Kant, "Tanrı" adını veririz diyor. Tanrı salt pratik aklın postulatı olarak vardır; bir anlama yeteneği ve irade olarak evrenin bütününü yönetmesi, mutluluğa yaraşır olma ve mutlu olmayı birleştirmesi bakımından vardır (Heimsoeth, 2012, s. 138).

Kant, Tanrı'nın varlığının postulat olarak kabul edilmesinin ahlakın otonomluğunu zayıflattığını reddeder. Tanrı'nın varlığı kaosa karşı kozmosun devamı için zorunludur (Öktem 2007, s. 8). İnsanın eğilimlerine uyması, arzularını gerçekleştirmek istemesi, yarar değerlerine yönelmesi, onun doğaya bağlı yanından gelmektedir ve özgürlüğünün ona verdiği güçle ortaya konması mümkün olmaktadır. İnsanın bu doğal yanı ondan mutluluğa yaraşır olmasını ister; aynı zamanda başkalarının mutluluğunu da istemesini buyurur. Son tahlilde Kant'ta erdem, mutluluk ve ahlaklılık tam olarak birleşir. Saf ahlak yasasının bağlayıcılığını kesinkes ortaya koyan Kant, insanın arzuladığı yarar ile Tanrı'nın varlığı ve ölümsüzlüğünü şöyle bir araya getirir:

"Saf ahlak yasasının bir buyruk olarak her insanı göz yumulmayacak biçimde bağladığı kabul edilince, insan şöyle söyleyebilir: bir Tanrı'nın olmasını istiyorum, benim bu dünyadaki varoluşumun aynı zamanda doğa bağlantılarının dışında, saf bir anlama yetisi dünyası içinde bir varoluş olmasını istiyorum, en son olarak da sonsuza dek sürmek istiyorum; bunda israr ediyorum ve bu inançtan vazgeçmeyeceğim; çünkü benim yararıma olan herhangi bir şeyi göz ardı edemeyeceğimden dolayı, yararıma olanın yargımı kaçınılmaz olarak belirlediği tek durum budur (Kant, 1994, s. 155)".

Heimsoeth, Kant'ın ödev etiğinden dini etiğe kapı aralayan bir değerlendirme yapar: Kant'ın ödev etiği, ancak onun varlığını kabul ettiği Tanrı'nın buyruklarını zorunlu olarak dikkate almakla mümkün olacak gibi görünmektedir. Zira bütün eylemlerinde ve niyetlerinde ahlak yasasını gerçekleştirmeyi ancak kutsal bir varlık başarabilir. İnsanın bütünüyle kutsal bir varlık olması, kutsal bir istemeye ulaşması, bizim hayat deneyimlerimize göre olanak dışıdır. Bununla birlikte kutsal bir isteme, ahlaksal bir varlık için ulaşmaya çabalaması gereken son amaç, en yüksek mutluluktur. Burada yine insan varlığının sınırlarını aşan bir tamlık, aklın bir ödevi olarak karşımıza çıkar (Heimsoeth, 2012, s. 141).

Dini etikte eylemin iyiliği, doğruluğu, kötülüğü ya da yanlışlığı Tanrı'nın emirleri ile belirlendiği için O'nun buyurduğu iyi, men ettiği kötüdür ve ahlaki olanda, ilahi buyruğa uygunluk aranır. İlahi buyruğu referans alan teoriler arasında farklılıklar olmakla birlikte Gazzâlî, kendi etik teorisinde irade ve eylemin önemine dikkat çeker. Ona göre, iyi inançtan daha önemli olan iyi eylemdir ve bir Müslüman için iyi ve doğru eylemin ifası, ancak ahlakı, Kur'an ahlakı olan Hz. Muhammed'i taklit etmekle dolayısıyla birçok İslam düşünüründe de ifadesini bulan "Allah'ın ahlakı ile ahlaklanmakla" mümkündür. Zira bu ifade ahlakın kaynağını ortaya koymakla birlikte insana, eylemlerini Tanrı'nın sıfatlarıyla somutlaştırma firsatı sunmaktadır. İnsan için "ne yapmalıyım" ya da "nasıl yapmalıyım" soruları karşısında bir bakıma kolaylık ifade eden bu metafor sayesinde dini etik bir gerçekleşme zemini bulur ve bu yönüyle realist bir veçheye bürünür. Dolayısıyla ahlakın vahiyden bağımsız olamayacağına işaret edilir. Vahiyden referans alan dini etiğin pratik boyutlarının ve örneklerinin yine dinden bir referansla yani peygamber kurumuyla takviyesi, dini etik teorileri kendi içerisinde tutarlı ve hiçbir noktada boşluk bırakmayan sistemler haline getirmektedir.

Ancak dini etik teorilerin vahiy ile ortaya konan dinamik boyutunun kurumsallaşan dini pratiklerle statikleşmesi bu teorilerin, insan aklını saf dışı bırakan kuramlara dönüşmesi tehlikesini de beraberinde getirmektedir. Dini etiğin karşı karşıya kaldığı statik tehlikeyi fark eden Kant'ın, ödev etiğinde, insan aklına ve özgürlüğüne vurgu yaptığı görülmektedir. O'na göre bir eylemi ahlaki anlamda iyi yapan, o eylemin herhangi bir fayda veya taklit ürünü olarak değil ödevden gelmesidir. Ödev ise yasaya saygıdan dolayı yapılan eylemin zorunluluğudur. Bu yönüyle ahlaki iyi, ancak ve ancak akıl sahibi olan ve daima ona başvuran insanda bulunan yasaya uygunluktur. Eylemlerinde yasaya uygunluğu sürekli olarak araması gereken insan aklı, sorumluluğu kendisi için içsel bir vazife 
olarak alır. Bu noktada Kant'ın ödev etiğinde, ahlaki eylem, birey tarafindan içsel bir referansla ortaya konması gerekir. Hatta Kant ilahi buyruk gibi dişsal bir motivasyon ile belirlenen eylemin ahlaki olmadığını savunur. Zira klasik anlamıyla dini etikte referans dışsal bir motivasyondur. Kant'ın ödev etiğinde motivasyon, gündelik yaşamda kullanılan ifadeyle insanın içinden gelmelidir. Ve sonuçları ne olursa olsun doğru olanı tercih etmek ve eyleme dönüştürmek ödev olarak kabul edildiği gibi bunu yapmış olmaktan da büyük bir hoşnutluk duyulmalıdır.

\section{SONUÇ}

Kant'ın, ahlak sisteminin kaynağını, dışsal bir motivden ısrarla ayırmaya çalışmasının kendince haklı nedenleri vardır. Aslına bakılırsa Tanrı, ahlakı, kullarına belli kurallar vaz etmekten öte pratik örnekler üzerinden sunmuştur. Bu durumda ahlakın dinamik yönü daima açık bırakılmıştır. Ancak etik, belli şartlar altında nasıl davranmak gerektiğine dair ilkeler belirleyerek ahlakı pasifize etmektedir. Örneğin vahiy ve peygamber kıssalarında dolayısıyla dini etikte belirgin olan şey, birtakım örnek durumlarda alınması gereken tavır ve ortaya konması gereken eylem açıkça gösterilir. Herhangi bir ahlak kuralı vaz edilmez. Ancak her insan kendi zamanı ve kişisel pozisyonuna göre bu örnek eylemin kendisine sağladığı istikamette bir ilke ile kendi kararını kendisi verir. Hatta bu nedenle birçok ahlak tanımında eylemin kendiliğindenliğine vurgu yapılır. Burada ahlaki tutumun edinilmesinde ortaya çıkan iki önemli faktör söz konusu olur: birincisi ahlaki tutumu kazandıran örnek olay, ikincisi ise benzer durumlarda benzer davranışı sergileme potansiyeline sahip olan insan iradesi. Genel karakteri itibariyle dini etik, inananları, kıssalar ve örnek olaylar üzerinden motive ederek onlarda ortaya çıkması beklenen ahlaki eğilimler meydana getirir. Böylelikle istenen davranışların tekrarı ve içselleşme durumuna göre ahlaki olgunluktan söz etmek mümkün olur. Kant ödev etiği ile, ahlaki eylemi irade etmemiz konusunda bize motivasyon sağlayan ilkenin kaynağını otonom kılmak ister. Diğer taraftan hiçbir insan iradesinin, yaşadığı dünyadan bağımsız salt ilişiksiz bir düşünme yeteneğine sahip olduğu söylenemez. Davranışlarımız düşüncelerimizin, düşüncelerimiz kavramlarımızın, kavramlarımız da tecrübelerimizin ürünü olarak doğar. Tecrübelerimiz ise dünya ile ilişkimiz neticesinde oluşur. Bu nedenle Kant'ın salt pratik aklı ideal bir yaklaşım olmakla birlikte, dogma ve dayatmalar üzerine tesis edilen bir ahlaki düşüncenin yanlışlığına yaptığı vurgu bakımından daha fazla önem taşımaktadır.

Diğer taraftan Kant'ın ahlak metafiziğini temellendirme şekline bakıldığında dini etiğe benzer bir tutumu ortaya koyduğu anlaşılmaktadır. Kant'ın, ahlak yasasının koyucusu olarak Tanrı'yı ima eden ifadeleri ve bu yasanın nesnelliği için Tanrı'nın varlığını şart koşan yaklaşımı onun ödev etiğini bir tür ilahi buyruk etiğine dönüştürmektedir. Kant'ın, ahlakın kaynağı olarak "Tanrı" ifadesi yerine "akıl" kavramını kullanarak kaçınmaya çalıştığı ve insanların da kaçınmalarını talep ettiği şey, iyiyi istemenin dışsal bir özneden kaynaklanan dayatmanın buyruğu olarak algılanmasının önüne geçmektir. Kant her ne kadar, ahlak sistemini dini etiğin kavramlarından farklı ifadelerle sunmaya çalışsa da anlaşılan o ki ödev etiği, dini etiğin sekülarize bir formu olmaktan çok fazla uzaklaşamamıştır. Buna karşın, Kant’tan, ahlakın kaynağı Tanrı olsa bile ahlaki olanı O bildirdiği için değil, kendi arzu ve irademle ortaya koymam gerektiği için tercih etmemiz gerektiğini anlarız. Dolayısıyla doğru olanı yapmamın nedeni herhangi bir emir, ödül/ceza ya da motivasyon olmamalıdır; o sadece ve sadece kendi içimden gelerek, bilinçli ve kasti olarak, isteyerek ve her zaman için yapmalıyım diyebileceğim bir eylem olmalıdır. Bunun dışında, ancak hangi eylemin doğru olacağını seçebilmem ya da karar verebilmem için salt aklın postulatları olan özgürlüğüme, Tanrı'nın varlığına ve ölümsüzlük düşüncesine olan inancım ile bunu bilmeyi umabilirim. Sadece bu son ifadesi bile Kant'ın etik teorisindeki açı̆̆ı itiraf etmiş olduğunu göstermesi bakımından büyük önem arz etmektedir.

\section{KAYNAKÇA}

Akarsu, B. (2014). Çağdaş felsefe. İstanbul: İnkılap Kitabevi.

Akpınar, A. (2001). Allah'ın ahlakı ile ahlaklanmak. Tasavvuf: Illmi ve Akademik Araştırma Dergisi, 6, 61-80.

Aristoteles. (2014). Nikomakhos'a etik. (Trc. Saffet Babür). Ankara: Bilgesu Yayınc1lık. 
Berg, J. (1991). How could ethics depend on religion?. A companion to ethics. (Ed. Peter Singer) içinde. 525-533. Oxford: Blackwell Publishing.

Copleston, F. (2004). Felsefe tarihi 6/1/aydinlanma. İstanbul: İdea Yayınları.

Copleston, F. (2010). Felsefe tarihi 7/la/Alman idealizmi. İstanbul: İdea Yayınları.

Cevizci, A. (2002). Etiğe giriş. İstanbul: Paradigma Yayınları.

Cevizci, A. (2015). Etik ahlak felsefesi. İstanbul: Say Yayınları.

Demirtaş, M. (2013). Kant'ın “İnanca yer açmak için bilgiyi inkâr ettim” sözünün iman ve bilgi açısından değerlendirilmesi. Cumhuriyet Üniversitesi Illahiyat Fakültesi Dergisi, 17(1), 289303.

Fahri, M. (2018). İslam ahlak teorileri. İstanbul: Litera Yayınc1l1k.

Feldman, F. (2016). Etik nedir? İstanbul: Boğaziçi Üniversitesi Yayınevi.

Frankena, W. (2007). Etik. (Trc. Azmi Aydın). İstanbul: İmge Yayınları.

Gazzâlî. (1974). İhyâ 'u Ulûmid-Din. İstanbul: Bedir Yayınları.

Gazzâlî. (1994). El-Mustasfa/İslam hukukunda deliller ve yorum metodolojisi I. (Trc. Yunus Apaydın). Kayseri: Rey Yayıncılık.

Gazzâlî. (2005). Esma-i hüsnâ şerhi. (Trc. M. Ferşat). İstanbul: Ferşat Yayınları.

Gensler, H. J. (2004). Ethics contemporary readings. New York: Routledge.

Gökberk, M. (1999). Felsefe tarihi. İstanbul: Remzi Kitabevi.

Heimsoeth, H. (2012). Kant'ın felsefesi. (Trc. Takiyettin Mengüşoğlu). Ankara: Doğu Batı Yayınları.

Kant, I. (1994). Pratik aklın eleştirisi. (Trc. İoanna Kuçuradi). Ankara: Türkiye Felsefe Kurumu.

Kant, I. (2015). Ahlak metafiziğinin temellendirilmesi. (Trc. İoanna Kuçuradi). Ankara: Türkiye Felsefe Kurumu.

Kant, I. (2017). Salt aklın sinırları dâhilinde din. (Trc. L. Çilingir - A. Avcan). Ankara: Elis Yayınları.

Kılıç, R. (2003). Ahlakın dini temeli. Ankara: Türkiye Diyanet Vakfı Yayınları.

Kuçuradi, İ. (2018). Etik. Ankara: Türkiye Felsefe Kurumu Yayınları.

Korkmazgöz, R. (2015). Gazzâlı̂'de hüsün-kubuh meselesi. Ondokuz Mayıs Üniversitesi Ilahiyat Fakültesi Dergisi, 39, 31-60.

Nuyen, A. T. (1998). Is kant a divine command theorist? History of Philosophy Quarterly 15(4), 441453.

Öktem, Ü. (2007). "Kant ahlakı”. Araştırma 18, 11-22.

Pieper, A. (1999). Etiğe giriş. (Trc. V. Atayman - G. Ö. Sezer). İstanbul: Ayrıntı Yayınları.

Platon. (2017). Kriton. (Trc. Ahmet Cevizci). İstanbul: Say Yayınları.

Stroll, A. Ve Popkin, R. H. (1956). Philosophy made simple. New York: Routledge.

Türkeri, M. (2017). Etik kuramları. İstanbul: Lotus Yayınevi.

Tüzer, A. (2015). Tanrı’yı oynamak: Kant etiğinin kritiği. Beytulhikme: An International Journal of Philosophy 5(2), 139-167.

Weber, A. (1998). Felsefe tarihi. (Trc. H. Vehbi Eralp). İstanbul: Sosyal Yayınları. 